\title{
Metaphysical Language Game and the Word-play Modality in V. Nabokov's Novelism and Poetry
}

\author{
Elena Proudchenko ${ }^{1, *}$, Ludmila Melnikoa ${ }^{2}$, and Anna Kryzhanovskaja ${ }^{1}$ \\ ${ }^{1}$ FSAEI HE Industrial university of Tyumen, Department of Intercultural Communication, 625000 Tyumen, Russia \\ ${ }^{2}$ FSAEI HE Tyumen State University, Department of Foreign Language and Intercultural Professional Communication, 625000 Tyumen, \\ Russia
}

\begin{abstract}
This article discusses the unique linguistic consciousness of V. Nabokov, formed in a multilingual environment. The method of philosophical interpretation of the text was used in V. Nabokov's works analysis. It is revealed that in the multicultural environment V. Nabokov created an artful, nonstandard language by means of the original language game and word making and affecting, perhaps unconsciously, the logical and philosophical concept of Wittgenstein's "language game". The language of V. Nabokov's poetry is defined as a way to destroy the experienced, but unwittingly resurrected, i.e., what can be considered experience and memories, and at the same time self-creation through poetry. However, early criticism of Nabokov-Sirin's poetry is rather skeptical about the author's ability to touch or express metaphysical aspects of life.
\end{abstract}

\section{Introduction}

Despite the specific, almost observable nature of language use patterns, they should not be confused with cognitive content or knowledge that can be found in (classical) scientific explanations. According to Wittgenstein, all explanations themselves are part of a logical or conceptual structure, but not explanations of this structure. Logic is not a type of explanation; it cannot be stated, but only shown. This is something being revealed under the influence of the language by means of the word-play modality and in some respect metaphysical language intuition. The so-called metalinguistic awareness as felicity to externalize any language not only as a set of showpieces, but also as a process, as well as awareness that language has much higher potential than independent isolated language symbols can give adjunctive emotional shadows to poetic language. Moreover, the words can be dissociable and abstracted from their referents, i.e. their meanings "living" first in mind assume definite connotation, namely, additional attributes and contributory to the core concept. All these can make for deeper understanding and analysis of the characteristic features of the language game in Nabokov's writing. That is why Wittgenstein affirmed that we must remove our conceptual blinders and in the language we should see the explication of many areas, in which he worked. "Do not think, but look!" he exclaims with impatience at some point in the Philosophical Treatise.

Russian Émigré is a cultural-historical concept reflecting the life and fate of several waves of Russian emigration. As a result of the upheavals caused by the revolution and civil war the "first wave" of emigration took from Russia a huge number of representatives of the cultural and scientific intelligentsia, which necessitated "preserving Russian culture and at the same time adapting to the new social environment" [1]. The entire elite of the Russian creative intelligentsia which responded to incredible events of the revolution and civil war turned into an exile and became a spiritual stronghold of the dying nation. Writers, poets, composers and philosophers - Russian emigrants organically integrated into the dynamics of European culture development. They acted as a guarantor of the preservation of Russian culture, mastering the modern tendencies of the philosophy of the XX century, but also successfully developing them in line with the newest European philosophical views.

V. Solovyov was the founder of the revival of the Russian theological philosophy. His views greatly influenced the works of P. I. Novgorodtsev (1866-1924), S.N. Bulgakov, N.O. Lossky, N.A. Berdyaev, S.L. Frank [2]. These representatives of the philosophical community continued their activities abroad. They worked mainly in the field of idealistic metaphysics and personal psychology or philosophical anthropology. Their research was based on ontology, which recognizes the existential and historical autonomy of the human spirit as a creation of God.

The Russian Émigré had a unique influence upon the history of world culture and played a still underestimated role in it. Even a totally insufficient list of eminent persons of Russian culture who were forced to emigrate enables us to imagine how intense their spiritual and intellectual life was. "Russian Émigré" is "a major

\footnotetext{
*Corresponding author: helenprud@yandex.ru
} 
historical and cultural phenomenon of the twentieth century" which left "an impressive cultural heritage" to descendants [3]. A special mission of Russian émigrés was to preserve traditions and values of Russian culture, which also requires "tireless attention to the Russian language in a foreign language environment" [3]. One of the most important roles was played by the Russian Emigré authors who set "the goal to preserve the language focused on the Russian classics" [4]. The world-famous writers in exile were I.A. Bunin, M.A. Aldanov, B.K. Zaitsev, A.I. Kuprin, D.S. Merezhkovsky, V.V. Nabokov; poets Z.N. Hippius, G.V. Ivanov, I.V. Odoevtseva, V.F. Khodasevich, M.I. Tsvetaeva. They had quite different destinies in emigration. Some of them wanted to return to Russia, others did not even dream of returning to their homeland which had turned into an evil stepmother for them. Nevertheless, all of them were focused on their creative work which is sure to have enriched the history of the world culture [5].

\section{The language phenomenon of V.V. Nabokov}

V.V. Nabokov is a unique case of a literary personality that turned out to be in a multicultural space. He was "a writer who achieved mastery, created a personal style and a kind of rhythm in two different languages" [6] both in Russian and in English. Exploring the language phenomenon of V.V. Nabokov it is important to take into account the fact that linguistic consciousness is one of the most important characteristics of a linguistic personality forming the uniqueness of a creative personality style [7]. The concept of linguistic consciousness is close to "such concepts as the linguistic world image, the strategy and tactics of the verbal behaviour" and "is implemented in the verbal behaviour." Consequently, the linguistic consciousness of a personality implies peculiarities of a person's verbal behaviour whose innermost being determines the situation of verbal communication, linguistic and cultural status, social status, gender, age, psycho-type, world-view, features of the life history, and other constant and "variable parameters of a personality" [8].

The multilingual environment of his family influenced greatly upon the language consciousness of V. Nabokov. The writer had equally fluent Russian, English and French in which he had communicated with his parents, English and French nannies, governesses and teachers since childhood, as well as with numerous multilingual books. "...I was an absolutely ordinary trilingual child in a family with a large library," V. Nabokov said about himself [9]. Although he wrote fluently in all languages known to him Russian and English became the leading languages in his creative work. When asked what language he thought V. Nabokov always answered that he was thinking in images. Such kind of non-verbal thinking is typical of a naturally bilingual person because "images are always wordless," but then the verbalization of images happens, and "suddenly a silent film begins to speak, and I recognize its language" [9].
Nabokov's jump from Russian to English in writing, from poetry to prose reminds us Wittgenstein. His attempts to get over philosophy and his imaginary dissociation from the main framework of the "Logical Philosophical Treatise" turning to the philosophy of "linguistic games" distinguishes his writer's manner and endowment. Far from the Russian-speaking environment V. Nabokov experienced a shortage in sources of the contemporary rapidly replenished Russian language "and in his work he focused on the age-old classical form of the language of Dahl's dictionary" [10]. Consequently, the use of the archaic, obsolete vocabulary in the metropolis and frank contempt for the so-called Soviet language, i.e. the language of the totalitarian regime with which the writer was well acquainted is the characteristics of the Nabokov style. Despite of all this Nabokov followed the works of the Soviet writers with deep interest simultaneously creating his own skillful, unique language, revealing the diverse potential of the Russian language through a kind of peculiar word-play and word-creation. [11], At first sight it is chaotic in terms of chronological order or movement from one phenomenon to another. However, in a twisted way it follows and involves simultaneously and casually and possibly unconsciously the existing worlds of philosophical ideas, particularly logical-philosophical concept of Wittgenstein's "language game".

\subsection{Nabokov's "language games"}

"Language games" according to Wittgenstein are a complete communication system closely intertwining language and actions. This term was introduced by Ludwig Wittgenstein in his Philosophical Studies (1945) and used to describe language as a set of generally accepted rules in which the speaker is involved. Typical poetic characteristic features of a language game are the use of metaphors and paraphrasing, changing the literal meaning of a phrase into a figure of speech, word formation, phono- semantic operators (sound repetition and paronymical attraction, anagramming) etc. The game involves the compliance with certain rules which are not always possible to formulate accurately since each game requires its own unique rules. For different games various "combinations" and passages are set due to which the game can function as such and differ from other games. A game without rules is not a game. Any game must involve components of creativity and imagination. According to Wittgenstein's theory a language is not a static system. The language is diverse and tends to develop dynamically whereas the language game is a synthesis of language and activity in process of human life.

The words themselves having played their role are no longer so necessary. Wittgenstein in his Logical and Philosophical Treatise concludes: "My suggestions are explained by the fact that the one who understood me finally understands their meaninglessness. If he rose up with their help, on them and higher than them so he should throw off the ladder after he had climbed it up. He must overcome these proposals, only then he will 
correctly see the world". Definitely, Wittgenstein is a bit cunning himself because it is impossible to overcome a language and we do not claim that the rational mystic Nabokov is similar to the rational mystic Wittgenstein in his desire to overcome his own verbal constructions. Nevertheless, whether Nabokov "had risen himself to the words" and "higher than them" or not, he attempted to "drop the ladder". "Vladimir Nabokov delegated the right to destroy his own youthful literary workshop to the main character Fyodor Godunov- Cherdyntsev of his novel "The Gift" [12]. "There are verses about parting, about death, about the past. It is impossible to determine ...the exact time of change in relation to poetry creativity ...But how painful it was to break all this, to scatter, to forget! False skills held tight, accreted words did not want to be disengaged. The verses were neither inherently bad nor good, but their combination in groups, frankpledge of rhymes, and harmonized rhythms - all this made them scary, vile, and dead" [13].

Similarities with Wittgenstein have been noted above. "The concept of the language game is of particular importance for Nabokov. It is revealed at the phonetic, lexical, syntactic levels, and has a philosophical meaning. In Nabokov's poetry the wordplay appears as the main principle of creativity, as the way of interacting with readers, as an essential condition for creating the conventional order in the text" 14]. It is also necessary to note that according to Wittgenstein "a language game" is a "form of life": "To order, to ask, to inquire, to talk are to the same extent a part of our natural life as to walk, to eat, to drink, to play" ("Philosophical Studies"). What kind of "life form" is his poetry for Nabokov? In his research of Nabokov's works Viktor Yerofeyev stated that "...the main plot (...) is the adventures of "ME" in the illusory world of scenery and the search for such a state of stability by "ME" that would enable to continue existence with dignity" [15].

However, it is worth paying attention to the problem whether it is legal to relate Nabokov's lyrics to the philosophical system of Wittgenstein. Are there any grounds for giving such a correlation, and if they are, what is the origin of these grounds? We must stop trying to impart a cognitive basis to the "language game" of the fiction, because "any language game is to some extend something unpredictable ... it is not based on [p. 20-21] any grounds. It is not reasonable" [16]. The willingness to trust and perceive the cultural factors being mostly textual materials as "reliable" makes a fictional narrative possible. That is, any language game is possible only if someone trusts something. As for St. Anselm, for Wittgenstein trust is a priori understanding; an individual trusts only in order to understand and takes a position in culture to influence it. However, this means accepting the radical uncertainty of any ultimate foundation or base for this culture. Assuming or implementing obligations with respect to something, we undermine any universal basis for this.

It is clear that in this particular case there is no possibility to reduce everything to the problem of direct influence or citation since Nabokov stated that he was not familiar with Wittgenstein's philosophy. In his interview with Alfred Appel in September 1966
Nabokov said that "he knew absolutely nothing about the Wittgenstein's writings and it was only in the fifties when he heard his name" (Nabokov, 1997, p. 597). It is obvious that in this light it is impossible to study Nabokov's lyrics from the point of view of the philosophical language game as poetic methods cannot be reduced to Wittgenstein's constructions. However, the thematic propinquity with Wittgenstein, which is actually present in Nabokov's poetry, is clearly tracked [17].

It is also necessary to take into account the fact that the comparison of philosophical and artistic meanings should not be carried out in this case, neither in terms of the chronological sequence of their generation, nor in terms of their direct impact on each other, nor in terms of building a genetic series. Briefly, from any point of view irreversible vector movement from one phenomenon to another should be assumed. Such a comparison can be made only based on the M. Bakhtin's principle which states that in culture "there is neither the first nor the last word" [18]. It means that the revealed meanings are accepted as being in the relations of cultural eventfulness with each other, having certain similarity, but neither borrowing any justification from each other nor quoting each other [17].

\subsection{The significance of the word in Nabokov's poetry}

The peculiarity of Nabokov's poetry is in its closest and penetrating relationship with the language which seems to fully reveal itself in it since the words here, according to Sartre, live like stones and trees resisting rationalizing interpretation and striving for self-affirmation as "these words" and not some others.

In other words, what is said by the poet in one way or another cannot be said otherwise. Nietzsche, being the most poetic among philosophers, understood this perfectly well when he spoke through the mouth of one of his characters: "He who writes in blood and parables wants not to be read, but to be memorized" (that is, NOT interpreted, NOT reinterpreted, NOT chattered). The word in poetry seems to be stable and firm. It names, lives, reigns, defines, provides a starting point, as in the famous poetry "I've built a monument myself, the one not made by man".

\section{The analysis of the duality of Nabokov's language}

To understand poetry means to intend and even feel obliged to give the word the right to be the Word, the Name, the Entity, but not a "sign" dissolving in a subjective understanding.

But other poets have some peculiar, specifically "un" or even "anti" - poetical way of words existence. Instead of proud and self-sufficient self-assertion in the poetry it chooses the path of the flickering elusive touch of the wind that has flown by, leaving a trace of touch in memory, soft, but yet amazingly tenacious. But what makes it so tenacious? Its own already not-being. Words 
in such poetry come to point out what is meant beyond words. We should not assume that this is a flaw or even a peculiarity of the creative manner, but rather manifesting duality of the language itself which reveals only when hiding, i.e. the word hides behind its meaning.

Vladimir Nabokov in his poetry brings the escape of the word meaning to a conscious, and even to a selfdetecting reception which is particularly striking and typical of this author:

Ничем не смоешь взгляда моего, тобой допущенного на мгновенье.

Не знаешь ты, как страшно волшебство бесплотного прикосновенья. (Стансы)

Do not wash away my gaze, you allowed for a moment. You do not know how scary The magic of ethereal touch. (Stanzas)

Nabokov's language is similar to this "indelible look": the trace, the memory of a meeting with something completely different remains, while the "instrument" itself is incorporeal. The combination of incompatible meanings and feelings in one space creates the effect of the ephemeral nature of the poetic Word and, at the same time, the strength and stability of something that the Word can only touch with the edge of its meaning, not even with its phonetics.

Среди обугленных развалин, средь унизительных могил не безнадежен, не печален, но полон жизни, полон сил (Поэт)

\section{Among the charred ruins, amid degrading tombs - not hopeless, not sad, but full of life \\ (Poet)}

...той черной маски профиль волчий и губы нежные твои. (Встреча)

\section{... of that black mask wolf profile}

and your tender lips.

(A meeting)

...бьет, скатывается, рыдая, твой задыхающийся смех. (Барс)

... beats, rolls, sobbing, your choking laugh.

(Leopard)
"Oh, I rhyme the rainbow and dust," Nabokov says about his method through the mouth of his hero. And not only the language escapes, but the hero himself, who in Nabokov's works is in almost all cases a deception.

Вот это — я и призрак чемодана; вот это - я, по улице сырой идущий в вас, как будто бы с экрана, я расплывающийся слепотой.

This is me and the ghost of the suitcase this is me, on the wet street walking in you, as if from a screen me bleeding with blindness.

Everyone can definitely conceive Nabokov as a sensitive stylist only, i.e. the one who values the external form above all, enjoying the non-objective play of brilliant phrases and even almost a postmodernist dissolving life in a language game. Nevertheless, one can still distinguish his poetry as poetical aids of selfexpression between what it is about. In the novel "The Gift" there is an interesting quatrain:

И в разговоре татой ночи сама душа нета-татот... безу безумие безочит, тому тамузыка татот... I v razgovore tatoy nochi sama dusha ne ta-tatot... bezu bezumiye bezochit, tomu tamuzyka tatot...

\author{
And in the conversation of that night \\ the soul itself is not ta-tatot \\ ...madness is without flow \\ That music tatot ...
}

Language speaks, but here it speaks of its inability to speak. "That one", " to that one", . On the one hand, "Who? To whom?", but on the other one, unspeakability of emotions, i.e. the word-play here that sounds in Russian as "bezu bezumiye bezochit" or "tatoy, ta-tatot, tatot" is capable to recapture the atmosphere of that night, and ceiling nervous strain, and tearing beatings of the heart.

\section{Discussion}

These at first sight counterintuitive examples of Nabokov's poetic language are aligned with Aurelius Augustine's paper "About the Teacher". Aurelius Augustine in his essay "About the Teacher" introduces a dialogue with Adeodatus on the problem of identifying certain signs. At first, the teacher and the student came to the idea that "a sign cannot be a sign if it does not mean anything", but immediately faced the problem that it is almost impossible to determine what "if", "nothing" and "of" mean. And if Adeodat could explain what "from" means then Augustine nevertheless pointed to 
insufficiency of the explanation: "did you understand that you were explaining to me now the most famous words using the same well-known words, that is you were explaining signs with other signs, while I wanted you to show me what these signs serve as signs." (cited from the Anthology of the Real Phenomenologist p.61)

The poet always turns out to be exactly in the same position: it is necessary to show the signs of what are his poetic signs, what reality breaks through the network of skillfully woven words. "I know more than I can express in words," says Nabokov, "and the little that I can express would not be expressed if I didn't know more" [19].

But what does "more" mean? Should we assume that the author expresses some special spiritual or mystical experience? Perhaps he has some kind of system of metaphysical ideas, which is only fragmentary in his poems, stories and novels? The early criticism of Nabokov-Sirin's works is rather skeptical about the author's ability to touch on or express the metaphysical aspects of being. V. Markov wrote to G. Struve on April 6, 1953: "Sirin is still a writer of limited possibilities and one theme ... He is a subtle rationalist, but he wants to be a mystic, crawls into the abyss, wants to realize the transcendent, and breaks into the wrong door without even noticing it. And this gives rise to lies." It is interesting to note the fact that for us the main thing is that he "wants", and whether he will manage to realize it is of no importance. What is important is the combination of rational and mystical in Nabokov's poetry. V. Aleksandrov writes that "the secrets of the irrational, knowable through the rational speech, are the Nabokov's definition of the "true poetry"" [19].

\section{Conclusion}

Thus, having considered some at first thought counterintuitive examples of Nabokov's poetic language, it's possible to confirm the idea that both the word-play modality and his language game are the brightest characteristic features of his poetic techniques that make his poetry emotionally deeper and sensuous. Despite the fact that the word-play can be very interpretive, nevertheless it allows to percept his poetry not so much at the level of distinct understanding as revealed feelings.

Based on the above thoughts of the authors who had studied the works of V. Nabokov and our own ideas, we consider very difficult and still not fully studied language of V. Nabokov's works as a certain "spiritual exercise" namely, the certain way of destroying something felt, experienced, but involuntarily resurrected, i.e. of what can be considered experience and already memories, and at the same time selfcreation through poetry.

\section{References}

1. P. Milyukov "Essays on the history of Russian culture"M.: Progress-Culture, 528 (1993) Retrieved from: http://lektsia.info/5x740c.html (2019)
2. K. Konotopova Philosophical comprehension of I. A. Ilyin's life (2013) Retrieved from:

https://revolution.allbest.ru/philosophy/00416379_0. html\#text

3. N. Golubev-Mohnatkina Emigre Russian language // Russian language abroad, 8-68 (2001)

4. N. Kozhevnikova The language of literature of the Russian Diaspora, Russian language abroad. M., 119-287 (2001)

5. S. Ikonnikova. History of cultural theories, Moscow, Publishing house Yurajt, 2, 474 p. (2018) Retrieved from: $\quad$ https://scibook.net/teoriya-literaturyiistoriya/kultura-russkogo-zarubejya-45633.html

6. Z. A. Shakhovskaya In search of Nabokov. Reflections. 319 (Kniga, Moscow 1991)

7. M. R. Naptsok Russian literary personality in the conditions of emigration: the language phenomenon Of $V$. Nabokov, Bulletin of the Adyghe state University. Issue. 2, 108-114 (2011)

8. S. E. Nikitina Linguistic consciousness and selfconsciousness of personality in folk culture, Language and personality. M., 34-40 (1989)

9. N. D.Melnikova. Nabokov about Nabokov and other things: Interviews, reviews, essays, Comp., comment. 704 (2002).

10. M. R. Napzok, word-Formative potential of artistic discourse (on the material of prose of Vladimir Nabokov) Philology, linguistics, didactics: theory and methods of research: collection of scientific works. 124-136 (2010)

11. M. R. Napzok Russian literary person in the conditions of emigration: language phenomenon $V$. Nabokov Bulletin of the Adyghe state University, Philology and art history, Series 2: 98-103 (2011)

12. O. Slavnikova Gift of Vladimir Nabokov, Literary matrix. The twentieth century: a Collection, 441-470 (2011)

13. V. Nabokov Gift (Azbuka, Moscow, 2016)

14. E. Cherkunova Philosophical basis of works of art V. V. Nabokov, Teacher XXI century 1, 287-291 (2009)

15. V. Erofeev In search of the lost Paradise. In the book.: Other shore. - L., Polytechnic, 7 -8 (1991)

16. H. Mcdonald The narrative act: Wittgenstein and narratology, Revue électronique publiée par Les Presses de l'Université de Montréal (2002) Retrieved from:

https://pum.umontreal.ca/revues/surfaces/vol4/mcdon ald.html

17. E. Lapushkina "...thereof one must be silent" ("ultima thule" Nabokov and the philosophy of silence) Vestnik St. Petersburg University. Ser. 9, 3, 83-90 (Saint-Petersburg, 2016)

18. M. Bakhtin To the methodology of Humanities, Aesthetics of verbal creativity. 361-373, (M.: Art 1979) 
19. V. Alexandrov Nabokov and otherworldly: metaphysics, ethics, aesthetics, Alethea, 9, ( $\mathrm{SPb}$, 1999) 